\title{
THE RELATIONSHIP BETWEEN THE APPROACH TO STRATEGIC MANAGEMENT AND INNOVATIVENESS IN COMPANIES OF VARIOUS SIZES
}

Regarding the discussion presented in the article, the size of a company often determines whether an innovation-oriented strategy can be implemented. This is also strictly connected with the adopted approach to strategic management (a planned long-term approach or a flexible one). The purpose of the article was therefore to examine whether there is a relationship between the approach to strategic management and the innovativeness in companies of various sizes. Two different aspects were considered: a flexible approach, understood as the dynamism of acting and responding to different changes, and a long-term and planned approach based on precise defining and implementing plans for further development. The results of the conducted research showed that in large enterprises, innovativeness involves responding strategically to challenges in the environment, rather than developing the planned concept in the long run. In small companies, however, it seems that innovativeness is not associated with the approach to strategic management - not only as the long-term concept, but also as the flexible approach. sizes

Keywords: innovativeness, approach to strategic management, companies of various

DOI: $10.15611 /$ aoe.2018.1.09

\section{INTRODUCTION}

In 1986 Barney presented the strategic factors of market success which he believed include expectations, fortune and strategy (Ong, Ismail, Goh, 2010). The list of these factors should now be extended by innovativeness, which can be assumed to be essential to determining the strategic position of companies. In the age of technology, due to growing competitive pressure, the increased importance of innovativeness seems to have become a key success factor (Porter, 1985; Ahad, Osman-Gani, 1999). Innovativeness can be regarded as a result of planned actions, aimed at implementing adopted strategic priorities (Keizer et al., 2002), which means that it is connected with the particular approaches to strategic management. The term 'innova-

\footnotetext{
* Department of Strategic Management, Wrocław University of Economics.
} 
tiveness' is used in many aspects of business strategies such as innovative climate, attitude to innovation, innovative activity, innovative position or innovation management (Rolik, 2013). This promotes changes in strategic management, imposing the necessity of complying with the requirements and standards that are adopted as a part of the approach to strategic management fostering innovativeness.

The purpose of the article is to determine whether or not there is a relationship between the approach to strategic management and innovativeness, and whether it differs in small and large companies. The main hypothesis was that in small and large enterprises, innovativeness is based on different approaches to strategic management. Specific hypotheses were also formulated according to which in small companies, innovativeness is based on the concept of a flexible approach to strategic management and in large enterprises the foundation of innovativeness is a long-term approach to strategic management. In order to achieve the research goal, the hypotheses were tested with Kendall's tau correlation.

\section{INNOVATIVENESS AND BUSINESS GROWTH}

Investigating the influence of innovativeness on organizational performance is quite popular in academic research (Cooper, 2000; Damanpour, Gopalakrishnan, 2001; Zimmerer et al., 2002). A positive correlation between innovativeness, growth, increased sales and increased productivity has been observed so far (Baker, Sinkula, 2009; Subramaniam, Youndt, 2005). These assumptions are confirmed by the results of analyses that compare the capabilities and capacity of innovation-oriented and noninnovative businesses (Saunila et al., 2014; Hurley et al., 2004). In addition to the effects of innovativeness upon the financial performance of companies, many other advantages are worth noting. It allows adapting to the requirements of the environment, helps exploit opportunities, provides the foundation for a competitive strategy, boosts capacity, and enables to better satisfy consumer needs (Harmancioglu et al., 2009). Due to environmental changes, maintaining a competitive edge requires innovativeness, forcing companies to launch innovative initiatives, in order to survive, grow and defeat their competitors (Denton, 1999).

While the importance of innovativeness for business growth is undisputable, researchers seem to be unequivocal in how they define this concept (Harmancioglu et al., 2009). One perspective emphasizes the willingness to take innovative actions (Damanpour, 1996). From the market 
perspective it is assumed that innovativeness manifests itself in a new presentation of products and technology (Boer, During, 2001). The proposals of various authors refer to the classic definition, defining it as a measure of the degree of 'newness' of an innovation. This assumes the first successful market introduction of a product or process and has an iterative nature (Garcia, Calantone, 2002). Two assumptions can be made when searching for the shared features of the presented definitions. Innovativeness means making changes to enhance competitiveness. Those changes can affect various areas such as products, services, technologies and strategies, or management functions such as production, marketing and PR (North, Smallbone, 2000). When pointing out the actions, innovativeness means introducing new products, processes (operational innovation) and business systems (Hovgaard, Hansen 2003). It can therefore be said that it also involves processes (Zarrabi, 2013).

\section{INNOVATIVENESS AND THE SIZE OF THE COMPANY}

When studying innovativeness, it seems important to analyse the differences in the approaches presented by businesses of various sizes. In 1942, Schumpeter assumed that large companies can maintain their competitive edge thanks to innovativeness. Ever since he pointed out the relationship between company size and the tendency to be innovative, these relations are often discusses in academic works (Mansfield, 1963; Rothwell, Zegveld, 1982; Ettlie, Rubenstein, 1987; O’Cass, Weerawardena, 2009). Company size is regarded as a key factor that impacts a company's activity and determines its growth based on investment, human capital, internationalisation and innovation (Marcelino-Sádaba et al., 2014).

Due to their unique features, potential and varied perceptions of opportunities and threats, companies of different sizes significantly differ in their strategic decisions. Small companies are more prudent in estimating their innovation costs and benefits. Large organisations have more opportunities to choose their strategies based on innovativeness (Kumar et al., 2012). In addition, with their financial advantage over smaller businesses, they can conduct innovation research (Cohen, Klepper, 1996). However, as research shows, the mere ability to incur high costs associated with substantial risks does not imply being innovative. Large companies are characterised by more red tape and less flexibility, which suppress or hinder the creativeness that is at the basis of innovativeness (Wagner, Hansen, 2005). 
Many researchers have tried to verify the assumption that innovativeness rises with the increase in the size of the business (McNulty, 1974; Lunn, 1982; Cohen et al., 1987; Amato et al., 1981; Audretsch, Acs, 1991). The results of their research are various. By investigating the differences between companies Bertschek and Entorf (1996) concluded that small and large businesses are more innovative than medium-sized ones. When interpreting the results of research into the entrepreneurial nature of small companies, Mintzberg (1973) suggested that small businesses show a tendency to run risks and to assume pro-active attitudes in the competitive struggle. Nowadays, due to changes taking place in their environment, smaller businesses pay more attention to profitability, competitiveness and risk (Hosseinzadeh et al., 2013). Many studies have confirmed that small companies have a limited capacity to become cost leaders, therefore most SMEs declare that they use a strategy of diversity as an efficient way of gaining a competitive edge (Box, Miller, 2011). When choosing such strategies, smaller companies have to meet the need to cut costs while launching new products and technologies (Pullen et al., 2009). Acs and Audretsch (1987) in turn, conducted their research from the perspective of competitiveness, and found that in markets with imperfect competition large companies are market leaders, whereas in markets with pure competition it is rather the case that small companies have a competitive advantage. By referring to some studies that analysed how specific industries may affect innovativeness in businesses of different sizes, it can be pointed out that there are no differences between companies in the high-tech industry, whereas in industries with slow technological progress, large companies have a competitive edge over smaller ones (Audretsch, Acs, 1991). The authors of similar studies, Laforet and Tann (2006), demonstrated that small companies, despite their limited resources, can compete with larger firms if they offer innovative products, services and innovative business systems. The level of innovativeness in processes, however, depends on an industry's requirements, in particular where the product innovation is considered to be the basis for increased competition.

Considering the results of many studies, it can be recognised that smaller businesses are more and more interested in exploring, developing, implementing and commercialising innovative solutions (Doree, Holmen, 2004; Hardie, Newell, 2011; Bigliardi, 2013). Under the current conditions of competition, small and medium-sized businesses are increasingly introducing innovations, in particular technological ones. This trend applies to various areas, also the sectors in their maturity phase or those affected by 
an economic crisis (Dimitriu, 2008). On the other hand, innovativeness (also often understood as uniqueness) is usually a necessity for small companies as they lack other competitive edges that are available to large businesses (such as benefits of scale, bargaining power, tradition and image).

\section{INNOVATIVENESS AND STRATEGIC MANAGEMENT}

The relationship between innovativeness and the approach to strategic management have been an interesting subject of research (Ansoff, Stewart, 1967; Freeman, 1974; Miles, Snow, 1978; Hambrick, 1983; Bryan, 1999; Matsuno and Mentzer, 2000). The important factors fostering innovativeness include the adopted strategy and the related strategic priorities which determine it in the long run. This could be defined as a strategic approach. Therefore, when looking at the relationship between innovativeness (as a result) and strategy, it seems necessary to develop an approach based on the priorities and defined actions necessary to implement that goal (Saunders et al., 2014).

A clearly identifiable area of research into strategic management is the analysis of the effects of innovativeness upon the competitiveness of the organisation (Calantone et al., 1995). This interest stems from the observation of organisations in which the level of competitiveness is determined by an approach fostering innovativeness which requires the ability to make use of innovation potential and knowing how to be innovative (Saunila et al., 2014; Caputo et al., 2002). Another important issue is the problem of the approach to strategy and innovativeness in businesses of various sizes. It can be pointed out that organisations of a different size show different attitudes to strategic management process and chosen priorities. As a result their strategy is contingent upon the organisation's potential.

\section{APPROACH TO STRATEGIC MANAGEMENT - BETWEEN LONG-TERM AND PLANNED APPROACH AND FLEXIBILITY}

The planning approach in strategic management dates back to the 1960s, when it was postulated that long-term plans be created and necessary resources be ensured to help implement developed growth visions (Chandler, 1962). The rationalistic concept, which provides the foundations for the traditional planning approach, enabled the assumption that it is possible to 
make accurate predictions and, what is more, to control the future and choose optimal solutions (Shivakumar, 2014). This resulted in paying excessive attention to the creation of plans with long-term time horizons and the function to lay out growth paths for businesses (Choonhaklai, Wangkanond, 2014). In this sense, the strategic plan meant the long-range intention that helped clearly define individual stages and specific measures (Gordon, 2005). As strategic management was developing, doubts started to emerge whether or not it is reasonable to create any rigid plans, in particular those that determine steps to be taken in the long term (Haines, 2000), which then become a factor that inhibits new ideas and development concepts (Beinhocker, Kaplan, 2002). Research results indicate diverse results, showing both the advantages and shortcomings of such an approach. As pointed out by Hill and Jones (2013), the long-term planning approach helps make better decisions and has a positive impact on performance. A study conducted across 656 organisations has shown that using formal planning procedures can be an efficient way of formulating strategies (Brews, Hunt, 1999). On the other hand, the research conducted by the McKinsey Quarterly showed that in a sample of 800 surveyed managers only $45 \%$ of them were satisfied with the process of long-term strategic planning. What is more, $23 \%$ of them admitted that most of their strategic decisions had been made regardless of their previous plans as they had resulted from conditions that had unexpectedly occurred in their environment. Hence, a strong urge to debunk the traditional process of long-term strategic planning as inefficient and diminishing the adaptation skills, and to replace the same with a more flexible concept of long-term growth (Dye, Sibony, 2007). However, despite the need to adapt the process of strategic management to the constantly evolving complexity of the environment, one should not forget the significance of planning and creating input concepts, which somehow give a direction to strategic activities while setting certain desired boundaries of action; thus it seems advisable to integrate the flexibility into the planning process while setting long-term visionary plans.

A key challenge for contemporary strategic management is to provide organisations with the capability to change continually and rapidly. Such changes affect both the environment and the whole organisation, including its resources, processes, internal structures and strategies. Therefore, when putting forward new solutions, particular attention is paid to the speed and flexibility of acting in conditions of turbulence, or even chaos. In this case, time becomes the most valuable factor that determines the survival, growth and success of businesses. That is the basis of the concept of the emerging 
strategy proposed by Mintzberg and Waters (1985). As proven by Jennings and Haughton (2002), forecasting does not play a major role in conditions of intense competition; the speed and efficiency of response are becoming increasingly more important, as they determine the ability to outdistance competitors. In this case the size of the company does not matter as 'it is not the big that eat the small but rather the quick that do so with the sluggish'. The literature emphasises that this involves undertaking initiatives in response to changes in the conditions of competition in order to grow and strengthen the organisation's competitive edge (Hitt et al., 1998). Such an approach can be applied when the company has sufficient resources and is interested in taking advantage of emerging growth opportunities. Pressure on flexibility results in flexibility being also considered in strategic terms (Hitt et al., 1998; Gerwin, 1993; Sanchez, 1995). When referring to strategic management, strategic flexibility can be defined as the ability to change strategy according to the changing environment (Evans, 1991) and its particular importance stems from initiating, creating, maintaining and implementting various options for the future (Bowman, Hurry, ${ }^{1994)}$.

Hence, it appears that the dilemmas of contemporary strategic management concern the evolution between long-term approach and flexibility, assuming the form of an integrated growth concept that should be adapted to the specific nature of each organisation. This can also be associated with its size, which determines not only the scope and character, but also the process of strategy creation and implementation and the adopted approach.

\section{FLEXIBILITY AS AN APPROACH TO STRATEGIC MANAGEMENT IN SMALL COMPANIES}

Research conducted by Link and Bozeman (1991) showed that product innovations developed by small companies seem to be at least of as much significance as those stemming from large businesses. This results from the fact that small businesses can use their strengths to respond quickly to changes. Adapting to the requirements of the environment and coping with technological and competitive uncertainty requires using flexibility (Patel 2011).

Adaptation is best implemented by those companies whose internal potential helps them adopt themselves to scarcely predictable and comprehensive changes in the environment. Strategic flexibility requires that the company's potential be developed in the following areas: leadership, key 
competences, human resources, production, organisational structure, information and innovative culture (Cingöz, Akdoğan, 2013).

Hence, flexibility is rather a characteristic trait of small companies (Weinrauch et al., 1991), and research into strategy differences between small and large companies has shown that it is, above all, small organisations that have the resources enabling them to better overcome growth barriers created by the environment, and to seize opportunities emerging in a given industry (Dean et al., 1998). However, when facing a global crisis, it is rather smaller businesses that are exposed to the risk of their flexibility being restricted as they have to struggle with a decline in demand or cash flow problems (Sharma et al., 2011). Therefore, it is hard to clearly state that the size of the company affects its flexibility, since this depends on many conditions of action, including the uniqueness of a specific industry. As shown by the findings of the research quoted above, this is rather a strategic priority typical of small businesses. Studies by O'Regan, Kling, Ghobadian and Perren (2012) have demonstrated that in small innovative companies, strategic management often occurs without formal planning and strategy in written form, but nevertheless it is done successfully.

\section{LONG-TERM AND PLANNED APPROACH TO STRATEGIC MANAGEMENT IN LARGE COMPANIES}

As indicated in some studies, it is large companies that give more weight to developing long-term operational concepts, and plan strategies with longer time horizons (Ates et al., 2013). Authors of the vast majority of studies point out that small and medium-sized businesses more often take short-term measures, whereas large organisations adopt a long-term horizon (Stewart-Knox, Mitchell, 2003). Large companies are also more likely to prepare formal reports describing their vision, their relationships with stakeholders, and priorities (James, 2013). It can be said that the larger companies appreciate more the importance of establishing formal documents describing long-term cooperation with business partners as they know that it can be a significant element in the ongoing competitive struggle (Awuah, Reinert, 2012).

Some researchers point out that the strategy of innovativeness is not favoured by formalisation and centralisation, which are rather typical of large businesses, because they inhibit the flow of information and ideas and discourage participation in strategic decision-making (Cohn, Turyn, 1984). 
On the other hand, as stressed by Normann (1971), centralisation understood as a concentration of decision-making tasks may turn out to be necessary to overcome the resistance against changes, which is a major complaint of many businesses, especially large ones. Then centralisation may become the only solution that allows the implementation of innovations (Zaltman et al., 1973).

\section{RESEARCH METHODS AND HYPOTHESES}

The results presented below are a part of a broader study on the evolution of the strategic management process connected with company development. The original research sample involved 150 entities, which were divided according to their size (50 small, 50 medium and 50 large companies). Although there are various definitions considering the criteria used, in this research the number of employees was chosen (Gilmore et al., 2013). Table 1 summarizes the industry structure of the sample confirming the diversified characteristics of the data obtained. The study was conducted using a direct questionnaire interview - the quantitative survey was carried out with the use of a method based on collecting the data in a standardized way. The legal form of the entities was joint-stock company. Half of them $(50.7 \%)$ were listed on the Warsaw Stock Exchange. In addition, all companies were established after 1989, and were founded on the basis of Polish capital. The population was defined considering the fact that stock market presence

Table 1

Sector structure of the sample

\begin{tabular}{l|r}
\hline \multicolumn{1}{c|}{ Sector } & \multicolumn{1}{c}{$\%$} \\
\hline Construction & 14 \\
\hline Engineering & 4 \\
\hline Finance \& Insurance & 9 \\
\hline Trade & 16 \\
\hline Informatics & 6 \\
\hline Investments & 2 \\
\hline Media & 1 \\
\hline Real Estate & 1 \\
\hline Healthcare & 4 \\
\hline Industry & 25 \\
\hline Technology \& Telecommunication & 4 \\
\hline Other Services & 14 \\
\hline
\end{tabular}

Source: own research. 
requires precise strategy formulation, as well as reporting on the progress in its implementation. It was assumed that the companies listed on the WSE are obliged to formally conduct the strategic management process as well as to specify their strategic priorities. The sample size was determined by the availability of data, as well as willingness to participate in the research (due to the confidential data discussed).

Based on the calculations performed for the significance level $\alpha=0.05$, the value of the maximum estimation error for the main part of the survey was determined to be $7.9 \%$ (the size of the general population was assumed as $\mathrm{N}=9519$ ). The respondents in the survey included company managing staff, i.e. Executive Directors, Managing Directors or the Management Board understood as the President and the Members of the Management Board. The interview was performed on the basis of a questionnaire containing 84 questions grouped according to 19 research areas. The 5-point Likert scale was used. The data collection enabled to study the perception of respondents, not the actual features of strategy. Those latent variables represent qualities that are not directly measured (Tabachnick, Fidell, 2001), and the constructs operating in the mindset of individuals (Borsboom, Mellenbergh, van Heerden, 2003).

Further research conducted for this paper involved selecting two groups of respondents, divided into small and large companies (depending on employment rate). Each group consisted of 50 entities. The research investigated the relationships between approach to strategic management and innovativeness across businesses of various sizes. For this purpose, the main hypothesis was proposed:

$\mathrm{H}$ : In small and large companies, innovativeness is correlated with various approaches to strategic management.

Two specific research hypotheses were also formulated:

$\mathrm{H1}$ : In small companies, innovativeness is correlated with the strategic approach favoured by orientation to flexibility and the dynamism of reaction.

$\mathrm{H} 2$ : In large companies, innovativeness is correlated with the strategic approach favoured by orientation to long-term and planned acting.

Based on the literature review (Fahy, Smithee, 1999; Dreyer, Grønhaug, 2004; Stevenson, Spring, 2007; Olhager, West, 2000) it was assumed that flexibility and the dynamism of response involves:

- Continuously searching for new areas of (market or product) activity - F1

- Introducing products into new market segments as a priority for action F2

- Expanding the product portfolio as a priority for action - F3 
- Being ready to modify the business profile in order to gain a customer - F4

- Operational flexibility and the speed of response as a critical competitive edge - F5

Based on the concept presented by Andersen (2000), Baker and Leidecker (2001),_long-term and planned acting involves in turn:

- Having a clear vision of the future - L1

- Precisely defining the company's position in a horizon of at least five years - L2

- Planning measures to achieve long-term objectives in a perspective of at least three years - L3

- Precisely specifying long-term plans (with a horizon of more than five years) - L4

- Working on strategy in an organised and planned way - L5 Including the concepts presented by Conarelli O'Connor (1998) and Damanpour (1991), innovativeness was recognised to include:

- Setting new industry standards (with regard to technology, products, organisation, etc.);

- Basing the company's main competitive edge on innovation and technology.

To estimate the reliability of the scales (areas) mentioned, Cronbach's Alpha was used. For the flexibility area the result was 0.736 , for long term acting area $-0,718$ and for innovativeness -0.729 .

\section{RESEARCH RESULTS AND DISCUSSION}

It is worth noting that the research sample can be considered as representing organisations that take measures to foster innovativeness because in the groups of both large and small companies the average number of answers given to the two questions was 3.8-3.9, as shown in Table 2. The respondents declared high levels of innovativeness - setting standards in other sectors and consider innovativeness as their key advantage, which is different than the general opinion that Polish companies are hardly innovative. No difference can be observed between large and small businesses, but it seems surprising that small companies declare themselves to be setting the industry standards.

As the main questions of the questionnaire used a Likert scale, correlations were determined using Kendall's tau correlation coefficient, which is a non-parametric measure of correlation for ordinal variables, to test the hypotheses. 
Table 2

Average innovativeness in companies of various sizes

\begin{tabular}{l|r|r}
\cline { 2 - 3 } & \multicolumn{1}{c|}{$\begin{array}{c}\text { Small } \\
\text { companies }\end{array}$} & $\begin{array}{c}\text { Large } \\
\text { companies }\end{array}$ \\
\hline $\begin{array}{l}\text { Setting new industry standards } \\
\text { (with regard to technology, products, organisation) }\end{array}$ & 3.8 & 3.9 \\
\hline $\begin{array}{l}\text { Basing the company's main competitive edge } \\
\text { on innovation and technology }\end{array}$ & 3.8 & 3.8 \\
\hline
\end{tabular}

Source: own research.

Firstly, it was intended to investigate correlations between various aspects of flexible and long-term approaches to strategic management and innovativeness. The results obtained are presented in Table 3. The innovativeness of small and large businesses is positively, yet weakly correlated with the strategic management, both in terms of a long-term and a flexible approach. As indicated by the results above, a statistically significant correlation could be obtained only in one case, for a group of large companies. Its average level proves the existence of a positive relationship between the flexible approach to strategic management in large companies and the innovativeness (0.497). This finding seems a little surprising as the innovativeness of large businesses involves rather a flexible approach to strategic management (although the stronger influence of the long-term approach could be expected in this case). The innovativeness of small businesses is less associated with flexible strategic management than is the case with large businesses (although it could be expected that the flexible approach to strategic management should be used to create innovativeness in small businesses than in large ones). Large businesses cannot project their growth, including introducing innovations, in the long run, because the conditions of such growth are unpredictable. To a relatively small extent,

Table 3

Correlations between the flexible and long-term approach to strategic management and the innovativeness of small and large enterprises

\begin{tabular}{l|r|c|r|r}
\cline { 2 - 5 } & \multicolumn{2}{c|}{ Small companies } & \multicolumn{2}{c}{ Large companies } \\
\cline { 2 - 5 } & Correlation & $\mathbf{p}$ & \multicolumn{1}{c}{ Correlation } & \multicolumn{1}{c}{$\mathbf{p}$} \\
\hline Flexible approach and innovativeness & 0.131 & 0.23 & $0.497 * *$ & 0 \\
\hline Long-term approach and innovativeness & 0.197 & 0.07 & 0.115 & 0.31 \\
\hline
\end{tabular}

** Significant correlation at the level of 0.01 (two-sided)

Source: own research. 
small businesses base their innovativeness on the approach to strategic management, which is not popular in this group (even in the flexible version, which is geared to responding within a shorter time perspective).

Next, the elements of the two approaches were investigated, and the results obtained for the two groups are presented below. Table 4 presents the findings regarding the correlation between the approach to strategic management associated with flexibility and innovativeness. The presented results are interesting as they show that in large companies the correlation between operational flexibility and innovativeness is markedly stronger that in small companies. Despite stereotypes, innovativeness in large companies involves, to a large extent, dynamism and flexibility, expressed in the willingness to take actions aimed at including innovative solutions and making necessary adjustments of the strategy. It can be presumed that large companies have financial and material resources as well as knowledge that are necessary to process information, which translates into innovative potential. Due to their extended structures and operational diversification, they can undertake experimental actions. An extensive system of collecting and analysing information both help to shorten their times of response.

Table 4

Correlations between the elements of flexible approach to strategic management and innovativeness

\begin{tabular}{l|r|r|r|r}
\cline { 2 - 5 } & \multicolumn{2}{|c|}{ Small companies } & \multicolumn{2}{c}{ Large companies } \\
\cline { 2 - 5 } & Correlation & \multicolumn{1}{c}{ p } & \multicolumn{1}{c}{ Correlation } & \multicolumn{1}{c}{$\mathbf{p}$} \\
\hline $\begin{array}{l}\text { F1 - searching for new areas of activity and } \\
\text { innovativeness }\end{array}$ & 0.117 & 0.33 & 0.171 & 0.16 \\
\hline $\begin{array}{l}\text { F2 - introducing products into new market } \\
\text { segments and innovativeness }\end{array}$ & 0.101 & 0.39 & $0.384^{* *}$ & 0 \\
\hline $\begin{array}{l}\text { F3 - expanding the product portfolio and } \\
\text { innovativeness }\end{array}$ & -0.072 & 0.53 & $0.255^{*}$ & 0.03 \\
\hline $\begin{array}{l}\text { F4 - being ready to modify the business } \\
\text { profile and innovativeness }\end{array}$ & 0.141 & 0.22 & $0.523^{* *}$ & 0 \\
\hline $\begin{array}{l}\text { F5 - operational flexibility as a critical } \\
\text { competitive edge and innovativeness }\end{array}$ & $0.296^{* *}$ & 0.01 & $0.425^{* *}$ & 0 \\
\hline
\end{tabular}

* Significant correlation at the level of 0.05 (two-sided)

** Significant correlation at the level of 0.01 (two-sided)

Source: own research.

The innovativeness of small companies is strictly associated (0.296) with recognising flexibility as a critical competitive edge in the business's strategy. To a much lesser extent, innovativeness involves the actions that 
are concentrated on modifying the business profile $(0.141)$, searching for new areas of activity $(0.117)$ or entering new market segments $(0.101)$, and in no case is associated with the strategy of expanding the product portfolio. Most probably this is due to the fact that such strategies require a potential that exceeds the capabilities of small companies. The innovativeness of large businesses is strictly associated with the general perception of flexibility as a strategic competitive edge $(0.425)$, but it is similarly correlated with strategies that involve modifying the business profile (0.523), entering new market segments $(0.384)$ or expanding the product portfolio $(0.255)$. Only the strategy of searching for new areas of activity (likely to be seen as more risky) shows a weaker relationship with innovativeness.

Table 5 shows the research findings and correlations between the individual elements of the long-term approach to strategic management and innovativeness.

Table 5

Correlations between the elements of the long-term and planned approach to strategic management and innovativeness

\begin{tabular}{l|r|r|r|r}
\cline { 2 - 5 } & \multicolumn{2}{|c|}{ Small companies } & \multicolumn{2}{c}{ Large companies } \\
\cline { 2 - 5 } & Correlation & $\mathbf{p}$ & Correlation & \multicolumn{1}{c}{$\mathbf{p}$} \\
\hline $\begin{array}{l}\text { L1 - clear vision of the future and } \\
\text { innovativeness }\end{array}$ & 0.169 & 0.15 & $0.338^{* *}$ & 0.01 \\
\hline $\begin{array}{l}\text { L2 - defining the position in a five-year } \\
\text { horizon and innovativeness }\end{array}$ & 0.138 & 0.25 & 0.129 & 0.31 \\
\hline $\begin{array}{l}\text { L3 - planning in a three-year perspective and } \\
\text { innovativeness }\end{array}$ & 0.072 & 0.53 & 0.1 & 0.42 \\
\hline $\begin{array}{l}\text { L4 - precisely specifying long-term plans and } \\
\text { innovativeness }\end{array}$ & 0.148 & 0.2 & $-0.275^{*}$ & 0.02 \\
\hline $\begin{array}{l}\text { L5 - working on strategy in an organised and } \\
\text { planned way and innovativeness }\end{array}$ & 0.118 & 0.3 & 0.227 & 0.06 \\
\hline
\end{tabular}

* Significant correlation at the level of 0.05 (two-sided)

** Significant correlation at the level of 0.01 (two-sided)

Source: own research.

In small businesses, innovativeness is rarely associated with visionary (0.169) and long-term planning (0.138); the conditions of innovativeness are relatively strong, yet still insignificant in created visions. In large businesses, innovativeness is strongly oriented by a clear vision of the future (0.338), but it is already much less embedded in planned measures (0.227), and precise long-term planning is rather negatively correlated with innovativeness $(-0.275)$; it does not promote and may stifle innovativeness. 
Therefore it is not true that in large companies, innovativeness is subject to long-term planning, although it is based on a clear vision of the future. Innovativeness requires defining the long-term duration of a clear vision and the expected results of the measures to be taken (often costly). In large businesses the process of developing visions is better organised and planned. Hence, the low negative correlation level obtained for clearly defined longterm plans indicates the need to maintain flexibility instead of a detailed planning approach. So it seems that innovativeness requires the integration of long-term measures plus a more flexible approach. Defining objectives and detailed guidelines on how to achieve them is a priority that large companies do not find to be that important. In large companies, innovativeness is largely associated with responding to market challenges. They are likely to have the potential to do that, but it is not sufficient (especially in the global market) to set long-term trends.

In small companies, innovativeness is not equated with long-term attitude and planned action either, but it is rather a result of dynamically responding to changes in the environment and the suggestions and expectations of customers. It is an attempt to respond to identified customer needs or adapt oneself to changing conditions of operation, which can hardly be equal to innovativeness. The findings of the research support the claim that a clear vision of the future and the innovativeness of small businesses are not correlated with each other. In a horizon of at least five years, precisely specifying long-term plans and defining the company's position remain unrelated to innovativeness. It can be supposed that in small businesses strategy work is less organised and planned. However, the investment resources, which are limited compared to those of large companies, may discourage precise planning in a long time horizon. Research shows that such businesses are innovative, but restrict their planning of innovativeness related activities in a long-time horizon. This means that no relationship between innovativeness and a long-term and planned approach to strategic management can be demonstrated.

To sum up the research findings, it should be pointed out that in small companies, innovativeness is markedly less correlated with flexibility and long-term planning than in large businesses. The latter, in turn, are characterised by the ability to combine innovativeness and operational flexibility. 


\section{CONCLUSION}

The research has shown that there is a relationship between innovativeness, size of the company and approach to strategic management presented. However, only a few of the correlations observed have any significance, moreover, the vast majority turned out to be inconsistent with the stated hypotheses.

Firstly, it seems interesting that the specific hypothesis whereby in large businesses innovativeness is contingent, above all, on a long-term approach to strategic management, was disproved. It was demonstrated that in large businesses, innovativeness is really strictly associated with strategic management, but against expectations, it is a relationship with a strategic response to challenges of the environment, which was supposed to be a trait characteristic for smaller companies (Roitzsch et al., 2012). The tendency to modify the business profile and launch products into new markets dominates the mechanisms of long-term future planning among the factors that determine innovativeness. That conclusion is different from the concept presented by Dougherty (1992). The second specific hypothesis was disproved, too. It turned out that in small companies, innovativeness is not correlated with the approach to strategic management. This applies to both the long-term concept of shaping the future and the flexible approach to its creation. The research showed that in general, innovativeness of small businesses is not associated with an approach based on a long term plan, which could allow one to conclude that it is mainly related to current operations. This confirms the results presented by O'Regan, Kling, Ghobadian and Perren (2012).

Although the two specific hypotheses were falsified, the main hypothesis was supported. The presumption that the correlations between innovativeness and the adopted approach to strategic management significantly differ between large and small companies was confirmed. There is no doubt that these differences turned out to be significant. In large businesses, innovativeness is strictly associated with strategic management in terms of responding to market requirements and being oriented to opportunities. In the long term, the innovativeness of large businesses is subordinate to a long-range vision, as was pointed out by Stewart-Knox, Mitchell (2003). No such relationship could be observed in small businesses. In this context, it can be concluded that both innovativeness and flexibility are different in small businesses than in large ones and depend more on operational than strategic management. 
The obtained research results seem to be a valuable inspiration for further analysis, not only to confirm the findings presented, which are often surprising, but also to identify their deeper causes. Firstly, it should be worth examining the actual sources and conditions of innovativeness in small companies. It is worth investigating whether or not they are strategically justified and actually limited to ongoing responding to challenges, and if yes, how they are formed and what is their main drive. Against this background, another serious research challenge arises to understand the nature of flexibility in small enterprises. It is worth identifying the stereotyped idea of flexibility in such businesses as their main force and competitive edge. The nature, framework and scale of this flexibility should be investigated. The study results show that it is possible to restrict flexible actions to minor limited responses, with the exclusion of thorough strategic undertakings.

In light of identified regularities, strategic management contingent on the innovativeness of large businesses also seems to be an interesting research problem. It would be valuable to find out how innovativeness needs are identified, how measures in this respect are initiated if they do not result from long-term concepts and plans. If the hypothesis that a flexible attitude to growth development is the actual source of such solutions proves correct, it should be investigated how this type of approach to strategic management affects the development and implementation of innovativeness processes. It is also worth investigating whether or not the industry in which a company operates has any impact on the strategic attitude and the innovativeness.

\section{REFERENCES}

Ahad, A., Osman-Gani, M., International Technology Transfer for Competitive Advantage: A Conceptual Analysis of the Role of HRD, "Competitiveness Review", No 9, pp. 9-18, 1999.

Amato, L., Ryan, J., Wilder, R., Market Structure and Dynamic Performance in US Manufacturing, "Southern Economic Journal", Vol. 47, No 4, pp. 1105-10, 1981.

Andersen, T., Strategic Planning, Autonomous Actions and Corporate Performance, "Long Range Planning", Vol. 33, pp. 184-200, 2000.

Ansoff, H., Stewart, J., Strategies for a Technology-based Business, "Harvard Business Review", Vol. 45, No 6, pp. 71-83, 1967.

Ates, A., Garengo, P., Cocca, P., Bititci, U., The Development of SME Managerial Practice for Effective Performance Management, "Journal of Small Business and Enterprise Development", 20(1), pp. 28-54, 2013.

Audretsch, D., Acs, Z., Innovation and Size at the Firm Level, "Southern Economic Journal", pp. 739-744, 1991. 
Audretsch, D., Acs, Z., Innovation, Market Structure, and Firm Size, "The Review of Economics and Statistics", Vol. 69, No 4, pp. 567-574, 1987.

Awuah, G., Reinert, V., Small Firms Use of Their Business Relationship to Cope with Increased Competition, "International Journal of Business Strategy", 12(2), pp. 36-38, 2012.

Baker, G., Leidecker, J., Does It Pay to Plan? Strategic Planning and Financial Performance, “Agribusiness", Vol. 17 (3), pp. 355-364, 2001.

Baker, W., Sinkula, J., The Complementary Effects of Market Orientation and Entrepreneurial Orientation on Profitability in Small Businesses", "Journal of Small Business Management”, Vol. 47 No 4, pp. 443-64, 2009.

Beinhocker, E., Kaplan, S., Tired of Strategic Planning?, "McKinsey Quarterly”, June 2002.

Bertschek, I., Entorf, H., On Nonparametric Estimation of the Schumpeterian Link Between Innovation and Firm Size: Evidence from Belgium, France, and Germany, "Empirical Economics", Vol. 21, No 3, pp. 401-26, 1996.

Bigliardi, B., "The Effect of Innovation on Financial Performance: A Research Study Involving SMEs, "Innovation: Management, Policy \& Practice", 15(2), pp. 245-256, 2013.

Boer, H., During, W., Innovation, What Innovation? A Comparison Between Product, Process and Organisational Innovation, "International Journal of Technology Management" 22.1-3, pp. 83-107, 2001.

Borsboom, D., Mellenbergh, G., van Heerden, J., The Theoretical Status of Latent Variables, "Psychological Review", No 110(2), pp. 203-219, 2003.

Bowman, E., Hurry, D., Strategy through the Option Lens: An Integrated View of Resource Investments and the Incremental-choice Process, "Academy of Management Review", Vol. 18, No 4, pp. 760-782, 1993.

Box, T., Miller, W., Small-Firm Competitive Strategy, "Academy of Strategic Management Journal", 10(2), p. 57, 2011.

Brews, P., Hunt, M., Learning to Plan and Planning to Learn, "Strategic Management Journal", No 20, pp. 889-913, 1999.

Bryan, A., Strategic Type, Market Orientation, and the Balance Between Adaptability and Adaptation, "Journal of Business Research", Vol. 45, No 2, pp. 147-56, 1999.

Calantone, R., Vickery, S., Droge, C., Business Performance and Strategic New Product Development Activities: An Empirical Investigation, "Journal of Product Innovation Management", Vol. 12, No 3, pp. 214-23, 1995.

Caputo, A., Cucchiella, F., Fratocchi, L., Pelagagge, P, Scacchia, F., A Methodological Framework for Innovation Transfer to SMEs, "Industrial Management \& Data System", 102(5), pp. 271-283, 2002.

Chandler, A., Strategy and Structure: Chapters in the History of the American Enterprise. M.I.T. Press, Washington, 1962.

Choonhaklai, S., Wangkanond, R., The Linkage Between Elements In The Strategic Planning Process: A Qualitative Study, "International Employment Relations Review", p. 33, 2014.

Cingöz, A., Akdoğan, A., Strategic Flexibility, Environmental Dynamism, and Innovation Performance: An Empirical Study, "Procedia Social and Behavioral Science", 99, pp. 582-589, 2013. 
Cohen, W., Klepper, S., Firm Size and the Nature of Innovation within Industries: The Case of Process and Product R\&D, "The Review of Economics and Statistics", Vol. 78, No 2, pp. 232-43, 1996.

Cohen, W., Levin, R., Mowery, D., Firm Size and R\&D Intensity: A Re-examination, "The Journal of Industrial Economics", Vol. 35, No 4, pp. 543-65, 1987.

Cohn, S., Turyn, R., Organizational Structure, Decision-Making Procedures, and the Adoption of Innovations, "IEEE Transactions on Engineering Management", EM-31, pp. 154-161, 1984.

Colarelli, O'Conor, G, Market Learning and Radical Innovation: A Cross Case Comparison of Eight Radical Innovation Projects, "Journal of Product Innovation Management", Vol. 15, Iss. 2, pp. 151-166, 1998.

Cooper, R., Product Innovation and Technology Strategy, "Research Technology Management", 43, 1, pp. 38-41, 2000.

Damanpour, F., Organizational Innovation: a Meta-Analysis of Effects of Determinants and Moderators, "The Academy of Management Journal", Vol. 34, No 3, pp. 555-590, 1991.

Damanpour, F., Organizational Complexity and Innovation: Developing and Testing Multiple Contingency Models, "Management Science”, Vol. 42, No 5, pp. 693-716, 1996.

Damanpour, F., Gopalakrishnan, S., The Dynamics of the Adoption of Product and Process Innovations in Organizations, "Journal of Management Studies", 38 (1), pp. 45-65, 2001.

Dean, T., Brown, R., Bamford, C., Differences in Large and Small Firm Responses to Environmental Context: Strategic Implications from a Comparative Analysis of Business Formations, "Strategic Management Journal”, 19, pp. 709-728, 1998.

Denton, D., Gaining Competitiveness through Innovation, "European Journal of Innovation Management", Vol. 2, Iss. 2, pp. 82-85, 1999.

Dimitriu, A., Increase of the Competitiveness of the Small and Medium-size Enterprises by Means of the Best Strategies of Development of Economic Activity, "Annals of the University of Oradea: Economic Science", 4(1), p. 245, 2008.

Dorée, A., Holmen, E., Achieving the Unlikely: Innovating in the Loosely Coupled Construction System, "Construction Management and Economics", 22(8), pp. 827-838, 2004.

Dougherty, D., Interpretive Barriers to Successful Product Innovation in Large Firms, "Organization Science", 3 (2), pp. 179-202, 1992.

Dreyer, B., Grønhaug, K., 2004, Uncertainty, Flexibility, and Sustained Competitive advantage", Journal of Business Research, Vol. 57, pp. 484-494.

Dye R., Sibony O., How to Improve Strategic Planning. It Can be a Frustrating Exercise, But There Are Ways to Increase Its Value, "Strategy Practise. McKinsey Quarterly", August 2007.

Ettlie, J., Rubenstein, A., Firm Size and Product Innovation, “Journal of Product Innovation Management", 4(2), pp. 89-108, 1987.

Evans, J., Strategic Flexibility for High Technology Manoeuvres: A Conceptual Framework, "Journal of Management Studies", Vol. 28, No 1, pp. 69-89, 1991.

Fahy, J., Smithee, A., Strategic Marketing and the Resource Based View of the Firm, “Academy of Marketing Science Review", Vol. 10, pp. 1-30, 1999. 
Freeman, C., The Economics of Innovation. Penguin, Manchester, 1974.

Garcia, R., Calantone, R., A Critical Look at Technological Innovation Typology and Innovativeness Terminology: A Literature Review", "The Journal of Product Innovation Management", Vol. 19, Iss. 2, pp. 110-132, 2002.

Gerwin, D., Manufacturing Flexibility: A Strategic Perspective, "Management Science", 39(4), pp. 395-410, 1993.

Gilmore, A., McAuley, A., Gallagher, D., Massiera, P., Gamble, J., Researching SME/Entrepreneurial Research: A Study of Journal of Research in Marketing and Entrepreneurship (JRME?) 2000-2011, "Journal of Research in Marketing and Entrepreneurship", Vol. 15 Iss. 2, pp. 87-100, 2013.

Gordon, G., Strategic Planning for Local Government, p. 45. Washington, 2005.

Haines, C., The Systems Thinking Approach to Strategic Planning and Management, p. 2. CRC Press, Florida, 2000.

Hambrick, D., Some Tests of the Effectiveness of Functional Attributes of Miles and Snow's Strategic Types, “Academy of Management Journal”, Vol. 26, No 1, pp. 5-26, 1983.

Hardie, M., Newell, G., Factors Influencing Technical Innovation in Construction SMEs: An Australian Perspective, "Engineering Construction and Architectural Management", 18(6), pp. 618-622, 2011.

Harmancioglu, N., Droge, C., Calantone, R., Theoretical Lenses and Domain Definitions in Innovation Research, "European Journal of Marketing”, Vol. 43 Iss. 1/2, pp. 229-263, 2009.

Hill, C., Jones, G., Strategic Management. An Integrated Approach, Cengage Learning, Mason, p. 26, 2013.

Hitt, M., Keats, B., DeMarie, S., Navigating in the New Competitive Landscape: Building Strategic Flexibility and Competitive Advantage in the 21st Century, "The Academy of Management Executive" 12.4, pp. 22-42, 1998.

Hosseinzadeh, M., Vesal, S. M., Shamsaddini, R., Kamel, A., Prioritizing Competitive Strategies in Iranian SME's Based on AHP Approach to Serve Economic Sanction, "International Journal and Management”, 8(16), pp. 48, 2013.

Hovgaard, A., Hansen, E., Innovativeness in the Forest Products Industry, "Forest Products Journal", Vol. 54, No 1, pp. 26-33, 2003.

Hurley, R.; Hult, G., Knight G., Innovativeness and Capacity to Innovate in a Complexity of Firm-level Relationships: A Response to Woodside, "Industrial Marketing Management", 34(3), pp. 281-283, 2004.

James, M., Sustainability And Integrated Reporting: Opportunities And Strategies For Small And Midsize Companies, "Entrepreneurial Executive", pp. 18-24, 2013.

Jennings, J., Haughton, L., It's Not the Big That Eat the Small. It's the Fast That Eat the Slow: How to Use Speed as a Competitive Tool in Business, "Harper Business", pp. 287-288, 2002.

Kumar, K., Boesso, G., Favotto, F., Menini, A., Strategic Orientation, Innovation Patterns and Performances of SMEs and Large Companies, "Journal of Small Business and Enterprise Development", Vol. 19, Iss. 1, pp.132-145, 2012. 
Keizer, J., Dijkstra, L., Halman, I. M., Explaining Innovative Efforts of SMRs. An Exploratory Survey among SMEs in the Mechanical and Electrical Engineering Sector in The Netherlands", "Technovation", 22, pp. 1-4, 2002.

Laforet, S., Tann, J., Innovative Characteristics of Small Manufacturing Firms, "Journal of Small Business and Enterprise Development”, Vol. 13, Iss. 3, pp. 363-380, 2006.

Link, A., Bozeman, B., Innovative Behaviour in Small-Sized Firms, "Small Business Economics", 3, pp.179-184, 1991.

Lunn, J., Research and Development and the Schumpeterian Hypothesis: Alternate Approach, "Southern Economic Journal", Vol. 49, No 1, pp. 209-17, 1982.

Mansfield, E., 1963, Size of Firm, Market Structure, and Innovation, "The Journal of Political Economy", pp. 556-576, 1963.

Marcelino-Sádaba, S., Pérez-Ezcurdia, A., Echeverría Lazcano, A., Villanueva, P., Project Risk Management Methodology for Small Firms, "International Journal of Project Management", 32, pp. 327-340, 2014.

Matsuno, K., Mentzer, J., The Effects of Strategy Type on the Market Orientation-Performance Relationship, "Journal of Marketing”, Vol. 64, No 4, pp. 1-16, 2000.

McNulty, P., On Firm Size and Innovation in the Schumpeterian System, "Journal of Economic Issues", Vol. 8, No 3, pp. 627-32, 1974.

Miles, R., Snow, C., Organizational Strategy, Structure, and Process. McGraw-Hill, New York, NY, 1978.

Mintzberg, H., Strategy-Making in Three Modes, "California Management Review”, pp. 44-53, 1973.

Mintzberg, H., Waters, J., Of Strategies, Deliberate and Emergent, "Strategic Management Journal”, No 6, pp. 257-272, 1985.

Normann, R., Organizational Innovativeness: Product Variation and Reorientation, “Administrative Science Quarterly", 16, pp. 203-215, 1971.

North, D., Smallbone, D., 2000, The Innovativeness and Growth of Rural SMEs During the 1990s", "Regional Studies", Vol. 34, No 2, pp. 145-57, 2000.

O'Cass, A., Weerawardena, Examining the Role of International Entrepreneurship, Innovation and International Market Performance in SME Internationalization, "European Journal of Marketing”, 43(11/12), pp. 1325-1348, 2009.

Olhager, J., West, B., The House of Flexibility: Using the QFD Approach to Deploy Manufacturing Flexibility, "International Journal of Operations \& Production Management", Vol. 22, No 1, pp. 50-79, 2002.

O’Regan, N., Kling, G., Ghobadian, A., Perren, L., Strategic Positioning and Grand Strategies for High-Technology SMEs, "Strategic Change", 2, pp. 199-215, 2012.

Ong, J., Ismail, H., Goh, G., The Competitive Advantage of Small and Medium Enterprises (SMEs): The Role of Entrepreneurship and Luck, "Journal of Small Business and Entrepreneurship", 23, pp. 373-391, 2010.

Patel, P., The Role of manufacturing flexibility in managing duality of formalization and environmental uncertainty in emerging firms, "Journal of Operations Management", Elsevier, 29, pp. 143-162, 2011.

Porter, M., Technology and competitive advantage, "Journal of Business Strategy", 5(3), pp. 60-78, 1985. 
Pullen, A., de Weerd-Nederhof, P., Groen, A., Song, M., Fisscher, O., Successful Patterns of Internal SME Characteristics Leading to High Overall Innovation Performance, "Creativity and Innovation Management", 18(3), pp. 209-212, 2009.

Roitzsch, K., Hacker, W., Pietrzyk, U., Debitz, U., How Do German SMEs Cope with the Increasing Need for Flexibility?, "Advances in Decision Science”, pp. 1-2, 2012.

Rolik, Y. A., A Complex Approach to Evaluating the Innovation Strategy of a Company to Determine Its Investment Attractiveness, "Social and Behavioral Sciences", Elsevier, 99, pp. 562-571, 2013.

Rothwell, R., Zegveld, W., Innovation and the Small and Medium Sized Firm.University of Illinois at Urbana-Champaign's Academy for Entrepreneurial Leadership Historical Research Reference in Entrepreneurship, 1982.

Sanchez, R., Strategic Flexibility in Product Competition, "Strategic Management Journal" 16.S1, pp. 135-159, 1995.

Saunders, M., Gray, D., Goregaokar, H., SME Innovation and Learning: The Role of Networks and Crisis Events, "European Journal of Training and Development", 38(1/2), pp. 136-149, 2014.

Saunila, M., Pekkola, S., Ukko, J., The Relationship Between Innovation Capability and Performance, "International Journal of Productivity and Performance Management", 63(2), pp. 234-249., 2014.

Sharma, D., Garg, S., Sharma, C., Strategies for SMEs after Global Recession, "Global Business and Management Research: An International Journal", 3(1), p. 58, 2011.

Shivakumar, R., How to Tell which Decisions are Strategic, "California Management Review", p. 83, 2014.

Stevenson, M., Spring M., Flexibility from a Supply Chain Perspective: Definition and Review, "International Journal of Operations \& Production Management", Vol. 27 Iss. 7, pp. 685-713, 2007.

Stewart-Knox, B., Mitchell, P., What Separates the Winners from the Losers in New Food Product Development?", Trends in Food Science \& Technology, 14, pp. 58-64, 2003.

Subramaniam, M., Youndt, M., "The Influence of Intellectual Capital on the Types of Innovative Capabilities, “Academy of Management Journal”, Vol. 48, No. 3, pp. 450-63, 2005.

Tabachnick, B., Fidell, L., Using Multivariate Analysis, Allyn and Bacon, Boston, 2001.

Wagner, E., Hansen, E., Innovation in Large versus Small Companies: Insights from the US Wood Products Industry, "Management Decision”, Vol. 43, Iss. 6, pp.837-850, 2005.

Weinrauch, D., Mann, O., Robinson, P., Pharr, J., Dealing with Limited Financial Resources: A Marketing Challenge for Small Business, "Journal of Small Business Management", 29(4), pp. 44-54, 1991.

Zaltman, G., Duncan, R., Holbek, J., Innovations \& Organizations. Wiley, New York, 1973.

Zarrabi, F., Alignment between Innovation Strategy and Outcomes, "Procedia Social and Behavioral Science", 75, pp. 18-24, 2013.

Zimmerer, T., Scarborough, N., Wilson, D., Essentials of Entrepreneurship and Small Business Management. Prentice Hall, Upper Saddle River, NJ, 2002.

Received: September 2015, revised: August 2017 